\title{
SISTEM KENDALI LAMPU RUMAH MENGGUNAKAN SMARTPHONE ANDROID
}

\author{
Agus Mulyanto $^{1)}$, Yeni Agus Nurhuda ${ }^{2)}$, Imam Khoirurosid ${ }^{3)}$ \\ 1), 3) Informatika, Universitas Teknokrat Indonesia \\ ${ }^{2)}$ Sistem Informasi, Universitas Teknokrat Indonesia \\ Jl. H.ZA Pagaralam, No 9-11, Labuhanratu,Bandarlampung \\ Email : agus.mulyanto@teknokrat.ac.id 1),agus.nurhuda@teknokrat.ac.id 2),imam_electra@yahoo.com ${ }^{3)}$
}

\begin{abstract}
Abstrak
Pemanfaatan energi listrik dewasa ini kurang efektif khususnya dalam hal penerangan penggunaan lampu di dalam ruangan, dimana sering kali dijumpai keadaan energi listrik yang dipakai untuk menerangi ruangan terbuang secara percuma karena kelalaian pemakai yang lupa untuk memadamkan kembali lampu ruangan apabila sudah tidak diperlukan lagi. Maka pada penelitian ini di buat sebuah prototype Sistem Kendali Lampu Ruangan yang dapat dikendalikan melalui Smartphone Android dengan menggunakan media komunikasi Bluetooth HC-05, dan mikrokontroler Arduino Uno R3 serta sensor LDR. Tujuan penelelitian ini adalah supaya pemakaian energi listrik ini dimanfaatkan secara tepat dan efisien dengan adanya sistem timer dan sistem pemberitahuan jika kondisi lampu dalam kondisi hidup dengan melakukan beberapa pengaturan. Sistem dapat mengendalikan lampu ruangan pada jarak 9-17 meter dengan kondisi ruangan yang bersekat-sekat maupun rumah 2 lantai, dan jika dikendalikan dari luar rumah maka jarak jangkaunya mencapai 30-60 meter. Jarak jangkau pengendalian di pengaruhi oleh kualitas Bluetooth yang dimiliki smartphone. Pengujian dengan menggunakan smartphone Cross A88, Smartfren C2, dan Lenovo, dan hasilnya menunjukkan bahwa Bluetooth smartphone Smartfren C2 memiliki jangkauan yang paling jauh yaitu 20 meter untuk dalam ruang tertutup, dan 62 meter dari raungan terbuka atau dari luar rumah.
\end{abstract}

Kata kunci: kendali lampu, bluetooth HC-05, arduino uno R3, LDR, smartphone android.

\section{Pendahuluan}

Energi listrik merupakan kebutuhan primer bagi masyarakat. Sumber energi listrik diciptakan berasal dari beberapa sumber energi lain diantaranya tenaga air, tenaga uap, tenaga nuklir, dan menggunakan tenaga bahan bakar minyak. Pemakaian energi listrik yang berlebihan akan mengakibatkan kelangkaan listrik, khususnya untuk energi listrik yang menggunakan tenaga bahan bakar minyak. Secara tidak lansung akan habis karena bahan bakar minyak merupakan sumber daya alam yang tidak dapat diperbaharui, ancaman pemadaman listrik secara bergiliran sering sekali terjadi Maka dari itu, energi listrik harus dapat dimanfaatkan secara optimal karena negara kita sedang mengalami krisis energi listrik.

Pemanfaatan energi listrik dewasa ini kurang efektif pasalnya banyak peralatan elektronik yang mengkonsumsi listrik secara berlebihan. Hal tersebut disebabkan karena para pengguna alat elektronik kurang sadar akan pentingnya energi listrik. Hampir semua alat elektronik menggunakan listrik untuk dapat bekerja. Salah satu peralatan elektronik yang mengkonsumsi energi listrik adalah lampu. Lampu merupakan suatu alat yang dapat menghasilkan cahaya sehingga dapat menerangi ruangan atau lingkungan sekitar dimana lampu tersebut berada. Lampu sangat dibutuhkan masyarakat khususnya dimalam hari atau didalam ruangan gelap. Namun, keadaan yang umumnya terjadi adalah ketika orang menggunakan energi listrik dimana sering kita jumpai energi listrik yang dipakai untuk menyalakan lampu terbuang percuma karena kelalaian pemakai yang lupa untuk memadamkan lampu tersebut masih tetap menyala walaupun tidak dipakai.

Kejadian seperti diatas dapat diatasi atau setidaknya diminimalisasi dengan teknologi Smartphone yang dapat menggantikan peran saklar manual[1]. Smartphone dengan sistem operasi Android semakin banyak tersedia di pasaran dengan harga yang semakin terjangkau. Sistem operasi Android sendiri bersifat open source yang dapat dimodifikasi sesuai dengan keperluan[1]. Dengan memanfaatkan perangkat keras yang sudah terdapat di Smartphone Android berupa pengaturan bluetooth dapat dibuat aplikasi berdasarkan fungsi tersebut [1]. Selain itu dalam proses pembuatan aplikasi tentunya tidak berbayar dan dapat dilakukan dengan bebas atau open source dan memiliki tampilan aplikasi yang bisa dimengerti pemakaiannya oleh pengguna.

Pemantauan dan pengendalian lampu dibutuhkan terutama pada lingkungan yang luas seperti lampu yang berada di pekarangan luar, tempat-tempat yang jarang dilalui sering tidak terpantau sehingga hal ini dapat menimbulkan beberapa kerugian, seperti biaya kebutuhan listrik, apabila lampu ini dapat terkontrol maka biaya dapat ditekan, kemudian kerugian lainnya adalah tidak terpantaunya kondisi lampu apakah masih menyala atau tidak.

Untuk memudahkan pengguna dalam memangkas pemborosan energi listrik tersebut, maka pada penelitian ini dibangun sebuah prototype sistem pengendali lampu 
ruangan menggunakan smartphone Android dengan menggunakan media bluetooth sebagai alat pengendali dan memantau penggunaan energi listrik.

\section{a. Arduino Uno R3}

Arduino adalah kit elektronik atau papan rangkaian elektronik open source yang di dalamnya terdapat komponen utama yaitu sebuah chip mikrokontroler dengan jenis AVR dari perusahaan Atmel yaitu menggunakan Atmega8, Atmega168, dan Atmega328 [2][3]. Arduino dapat digunakan untuk mengembangkan objek interaktif, mengambil masukan dari berbagai switch atau sensor, dan mengendalikan berbagai lampu, motor, dan output fisik lainnya[2]. Pada penelitian ini digunakan Arduino dengan chip mikrokontroler Atmega 328 sebagai pusat pengendali dan pengatur kerja untuk mengendalikan lampu. Bahasa pemrograman Arduino menggunakan bahasa $\mathrm{C}$ yang merupakan implementasi dari Wiring, sebuah platform komputasi yang didasarkan pada pemrograman pengolahan multimedia[3].

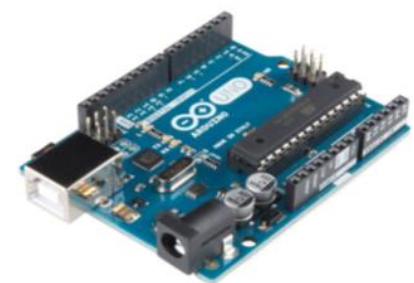

Gambar. 3. Bentuk Fisik Arduino

\section{b. Modul Bluetooth HC-05}

HC-05 merupakan modul bluetooth kelas 2 berbasis Bluetron BTR310 yang memiliki jangkauan sinyal hingga $10 \mathrm{~m}$. Modul ini berfungsi sebagai initiator (device yang memulai koneksi) maupun acceptor (device yang menerima koneksi). Catu daya modul sebesar 3,3 5 VDC. AT Command digunakan sebagai protokol komunikasi dengan host (mikrokontroler / PC) dan sebagai pemberi instruksi setting modul bluetooth. Modul ini dapat diaplikasikan dalam sistem transmisi data nirkabel.

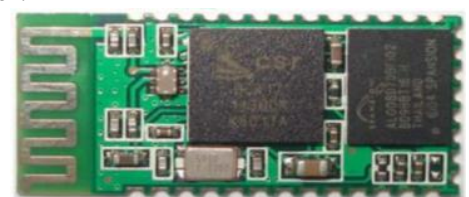

Gambar.4. Modul Bluetooth HC-05

\section{c. LDR (Light Dependent Resistor)}

LDR merupakan suatu sensor yang apabila terkena cahaya maka tahanannya akan berubah[4]. Biasanya LDR dibuat berdasarkan kenyataan bahwa film cadmium sulfide mempunyai tahanan yang besar kalau tidak terkena cahaya dan tahanannya akan menurun kalau permukaan film itu terkena cahaya.

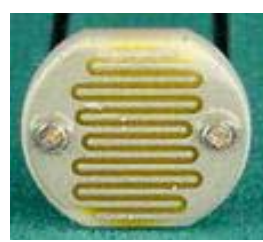

Gambar.5. LDR (Light Dependent Resistor)

LDR adalah komponen elektronika yang resistansinya akan menurun jika ada perubahan intensitas cahaya yang mengenainya. Jadi intensitas cahaya berbanding lurus dengan tegangan dan berbanding terbalik dengan tahanan LDR[8]. Fotoresistor dibuat dari semikonduktor beresistansi tinggi. Jika cahaya/foton dengan frekuensi yang cukup tinggi diserap oleh semikonduktor menyebabkan elektron dengan energi yang cukup untuk meloncat kepita konduksi. Elektron bebas yang dihasilkan akan mengalirkan listrik, sehingga menurunkan resistansinya. Besar tahanan LDR/fotoresistor dalam kegelapan mencapai jutaan Ohm dan turun sampai beberapa ratus Ohm dalam keadaan terang. LDR dapat digunakan dalam suatu jaringan kerja pembagi potensial yang menyebabkan terjadinya perubahan tegangan kalau sinar yang datang berubah.

\section{d. RTC (real time clock)}

RTC adalah sebuah jam elektronik berupa chip yang dapat menghitung waktu maupun tanggal dan tahun dengan akurat[7]. RTC dapat digunakan sebagai timer untuk pengendalian lampu menyala (on) atau padam (off) [8]. Chip RTC juga dapat kita jumpai pada komputer jenis desktop maupun jinjing (laptop) maka dari itu komputer kita dapat tepat dalam penghitungan waktu karena mempunyai osilator crystal walau komputer kita dalam keadaan mati (off) sekalipun. Salah satu chip yang terkenal dan mulai dikenal dengan shield RTC arduino merupakan jenis chip DS1307 dengan memakai osilator crystal 32,768 KHz. Dibawah ini merupakan kaki IC DS1307:

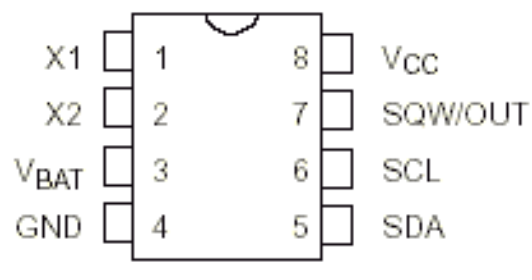

DS1307 8-PIN DIP

Gambar.6. Pin Out DS1307 


\section{Pembahasan}

\subsection{Perancangan Sistem}

Metodologi yang digunakan dalam pengembangan sistem kendali lampu dengan smartphone ini meliputi studi literatur, pengumpulan data, analisis kebutuhan baik kebutuhan perangkat keras dan perangkat lunak, perancangan sistem, implementasi sistem, pengujian sistem, hasil, dan pengambilan kesimpulan serta diskusi mengenai perbaikan atau saran yang dapat diambil untuk pengembangan aplikasi.

Sistem terdiri dari dua bagian besar, yaitu sebuah aplikasi perangkat lunak yang akan digunakan untuk sistem pengontrolan berbasis android dan sebuah sistem perangkat keras yang berperan dalam sisi mekanisme sistem. Aplikasi perangkat lunak dibuat dengan menggunakan Tools editor eclipse yang memungkinkan user untuk dapat mengakses tombol-tombol yang digunakan untuk mengendalikan, menyalakan, mematikan atau mengatur timer perangkat listrik berupa lampu dari smartphone yang memiliki sistem operasi android. Sistem perangkat keras menggunakan beberapa komponen penting yaitu arduino, bluetooth, relay, RTC, LDR dan sebuah smartphone android. Berikut ini Gambar diagram blok prinsip kerja sistem secara garis besar yang terdapat pada Gambar 7.

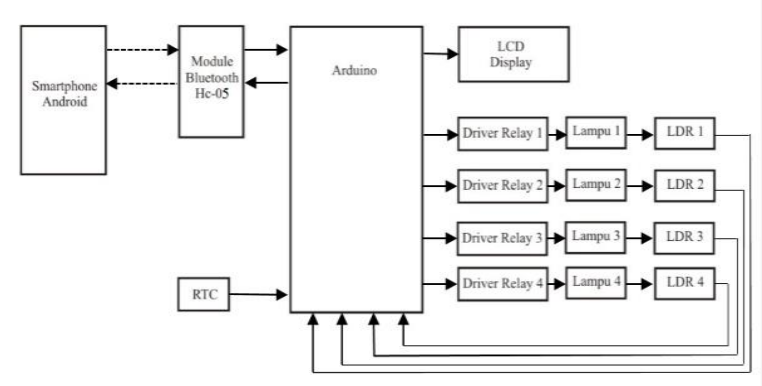

Gambar.7. Diagram Blok Sistem.

\section{A. Modul Bloetooth HC-05}

Rangkaian modul bluetooth ini difungsikan sebagai port serial yang dihubungkan ke arduino, dalam penelitian ini modul bluetooth ini berfungsi sebagai transreceiver dari smartphone android. Pada modul Bluetooth HC-05 hanya 2 pin pada port D yang dihubungkan ke arduino yaitu D0 (TX) dan D1 (RX). Berikut ini Gambar penggunaan pin HC-05.

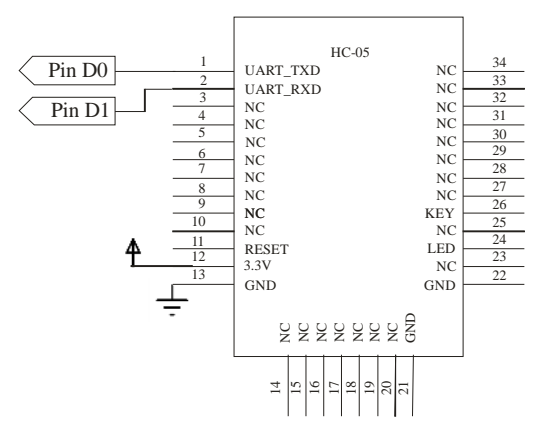

Gambar.8. Rangkaian Modul Bluetooth

\section{B. Arduino Uno R3.}

Dalam perancangan alat ini arduino berfungsi sebagai kontrol utama pengendalian pin-pin yang digunakan dapat dilihat dalam Gambar 9.

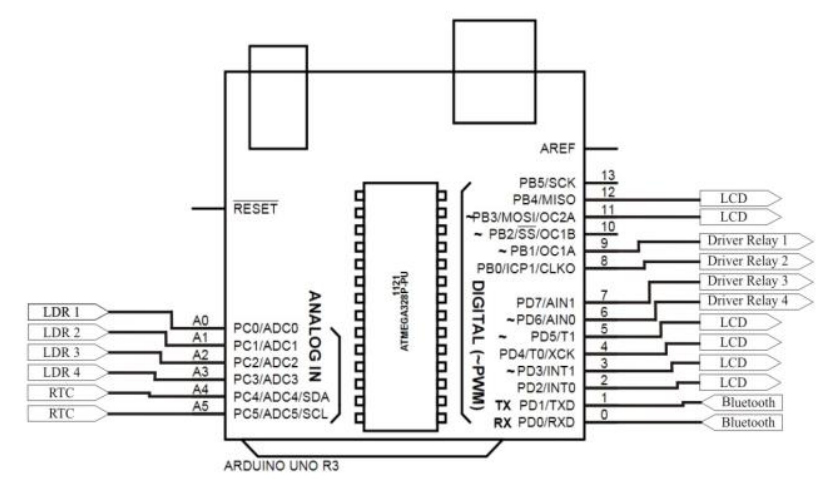

Gambar.10. Rangkaian Arduino Uno R3

\section{Driver Relay}

Driver relay ini digunakan untuk memutus dan menghubungkan supply listrik ke lampu. Rangkaian driver ini dirancang menggunakan transistor BD139 yang difungsikan sebagai saklar yang akan di kontrol dari arduino[9]. Bila sinyal ini berlogika tinggi (5 volt) lampu ruangan yang dikontrol akan terhubung dengan tegangan $\mathrm{AC}$, dan apabila sinyal berlogika rendah ( 0 volt) lampu yang dikontrol terputus dengan tegangan AC.

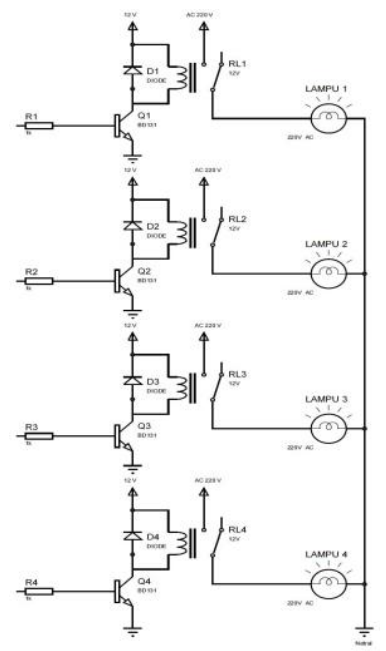

Gambar.11. Rangkaian Driver Relay[9] 


\section{Sensor $L D R$}

LDR (Light Dependent Resistor) berfungsi untuk mrngetahui kondisi lampu apakah lampu menyala, padam atau rusak. Pada rangkaian ini LDR akan mendeteksi cahaya lampu, jika lampu menyala maka hambatan LDR akan menurun hingga kurang dari 10 $\mathrm{K} \Omega$ sesuai dengan intensitas efektif dari berkas cahaya yang diterima bisa kurang dari $1 \mathrm{~K} \Omega$ pada intensitas cahaya sangat terang. Kondisi tersebut akan dimanfaatkan sebagai feedback ke arduino

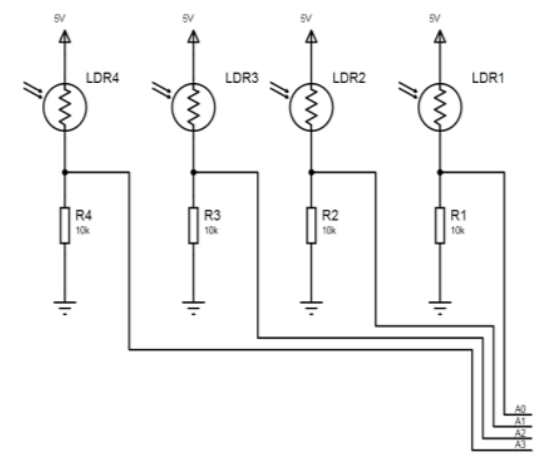

Gambar. 12. Rangkaian Feedback LDR

\section{E. Sistem Pewaktuan RTC (Real Time Clock)}

RTC adalah pewaktu digital yang dapat menghitung time maupun date dengan akurat. RTC pada sistem ini menggunakan chip DS1307 dengan memakai osilator crystal $32,768 \mathrm{KHz}$. RTC digunakan untuk timer yaitu kapan lampu akan menyala dan padam berdasarkan waktu yang telah diseting. Sistem pewaktuan yang dirancang ini seperti terlihat pada Gambar 13.

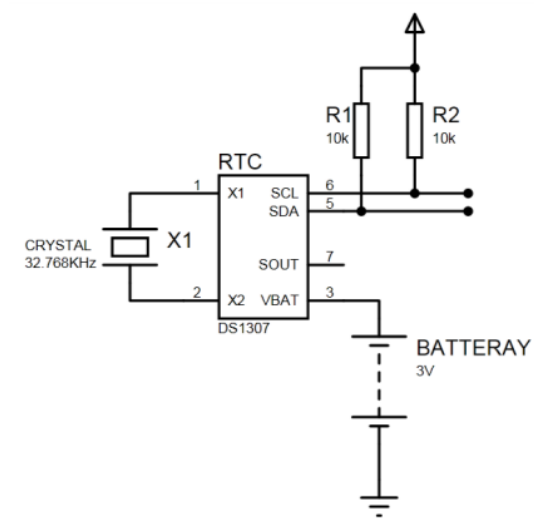

Gambar.13. Rangkaian Pewaktuan

\section{F. $L C D$}

Pada sistem ini LCD digunakan untuk menampilkan waktu, tanggal dan tahun yang akan digunakan untuk menseting timer.

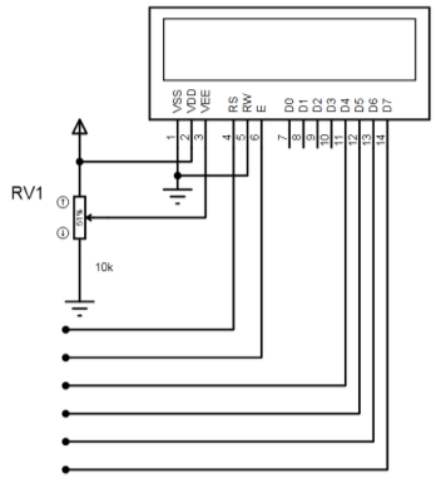

Gambar 14. Rangkaian LCD

\subsection{Pengujian Aplikasi}

Berikut hasil implementasi perancangan aplikasi kendali lampu yang dibuat pada platform Android. Total ada tiga fitur yang tersedia dalam aplikasi ini yaitu setting bluetooth, kontrol manual, dan timer. Sebelum masuk ke layout kontrol manual dan timer, user harus mengaktifkan perangkat bluetooth. berikut Tampilan koneksi bluetooth terlihat seperti pada Gambar 15 berikut.
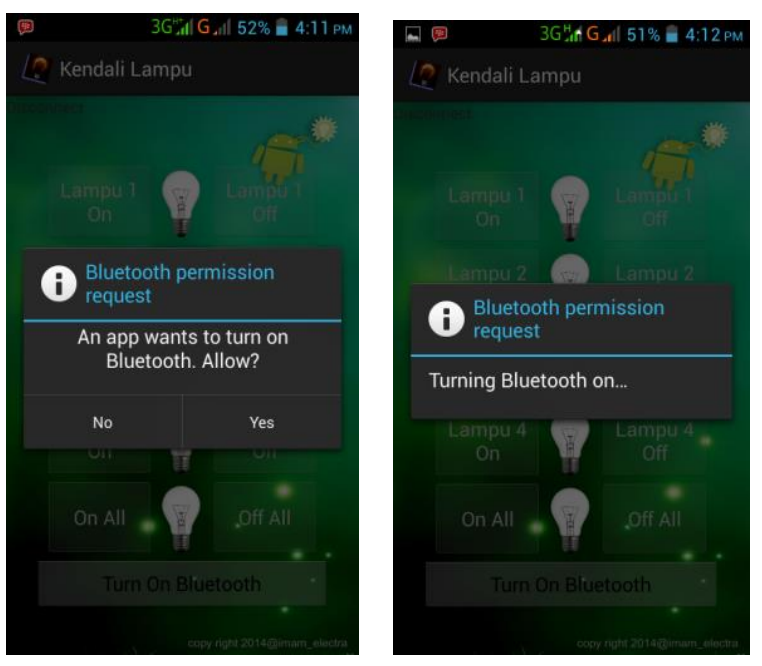

Gambar. 15 Tampilan Koneksi Bluetooth

Tampilan layout kontrol manual terlihat seperti pada Gambar 16. Dalam layout kontrol manual ini tersedia beberapa button yang berfungsi untuk menyalakan dan memadamkan lampu. User dapat mengetahui status terbaru lampu melalui menu ini. Sebelum menggunakan kontrol manual, user harus melakukan koneksi dengan device Bluetooth $\mathrm{HC}-05$ dengan menekan tombol connect. 


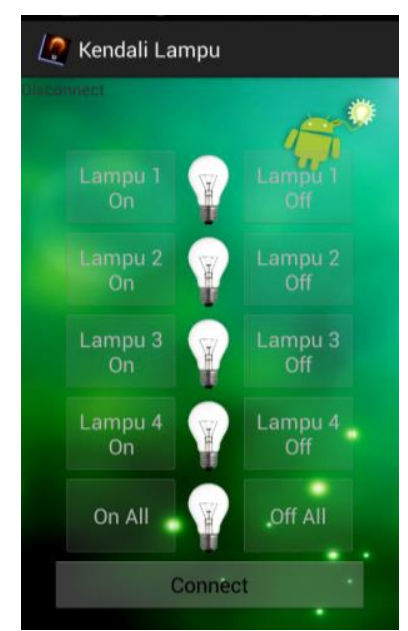

Gambar. 16. Tampilan layout Kontrol Manual

Tampilan layout Timer dapat terlihat pada Gambar 16. Pada layuot ini user dapat mengatur timer, user bisa memilih lampu mana yang akan diatur. Timer dapat diatur untuk kondisi menyala saja maupun padam saja, timer juga dapat mengatur kondisi semua lampu secara bersamaan atau individu tanpa interferensi pengaruh terhadap kondisi lampu yang lain.

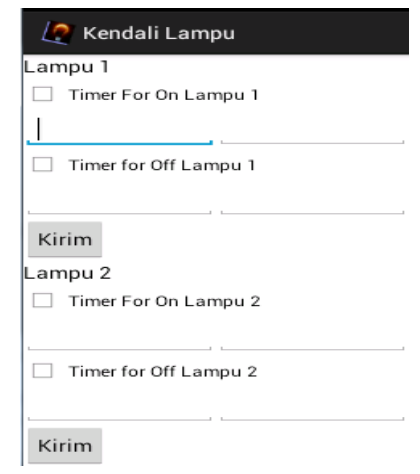

Gambar. 16. Tampilan layout Timer

\subsection{Pengujian Perangkat Keras}

Pengujian jarak komunikasi bluetooth yang penulis uji terdapat tiga vendor diantaranya Cross, Advan, Smartfren. Dari ketiga vendor tersebut dilakukan uji jarak komunikasi bluetooth di ruangan terbuka maupun ruangan tertutup. Panjangnya jarak komunikasi tersebut dapat dilihat dalam tabel 1 dan table 2 dibawah ini.

Tabel 1 Hasil Pengujian Jarak Komunikasi Bluetooth

\begin{tabular}{|c|c|l|l|}
\hline \multirow{2}{*}{ Vendor } & Jarak (m) & Lampu & Komunikasi \\
\hline \multirow{3}{*}{ Cross A88 } & 1 & Hidup & Berhasil \\
\cline { 2 - 4 } & 10 & Hidup & Berhasil \\
\cline { 2 - 4 } & 5 & Hidup & Berhasil \\
\cline { 2 - 4 } & 7 & Hidup & Berhasil \\
\hline
\end{tabular}

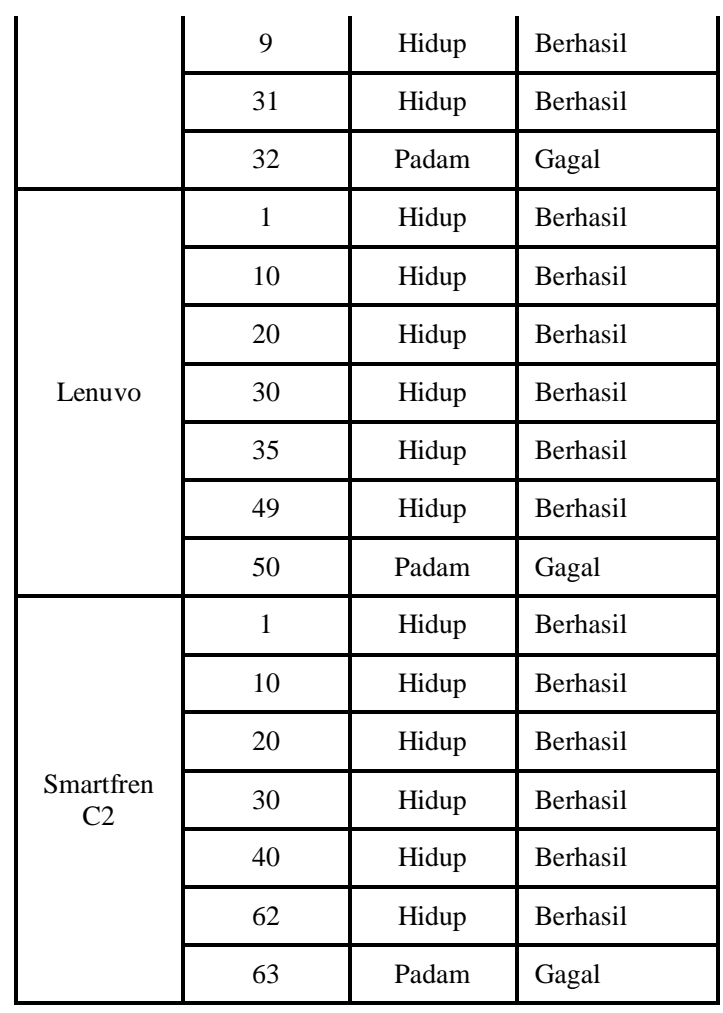

Tabel 2 Hasil Pengujian Jarak Komunikasi Bluetooth Pada Ruangan Terbuka (Line of Sight)

\begin{tabular}{|c|c|c|c|}
\hline Vendor & Jarak (m) & Lampu & Komunikasi \\
\hline \multirow{6}{*}{ Cross A88 } & 1 & Hidup & Berhasil \\
\hline & 3 & Hidup & Berhasil \\
\hline & 5 & Hidup & Berhasil \\
\hline & 7 & Hidup & Berhasil \\
\hline & 9 & Hidup & Berhasil \\
\hline & 10 & Padam & Gagal \\
\hline \multirow{7}{*}{ Lenuvo } & 1 & Hidup & Berhasil \\
\hline & 5 & Hidup & Berhasil \\
\hline & 7 & Hidup & Berhasil \\
\hline & 9 & Hidup & Berhasil \\
\hline & 11 & Hidup & Berhasil \\
\hline & 13 & Hidup & Berhasil \\
\hline & 14 & Padam & Gagal \\
\hline \multirow{7}{*}{$\begin{array}{l}\text { Smartfren } \\
\text { C2 }\end{array}$} & 1 & Hidup & Berhasil \\
\hline & 5 & Hidup & Berhasil \\
\hline & 10 & Hidup & Berhasil \\
\hline & 13 & Hidup & Berhasil \\
\hline & 15 & Hidup & Berhasil \\
\hline & 17 & Hidup & Berhasil \\
\hline & 18 & Padam & Gagal \\
\hline
\end{tabular}




\section{Kesimpulan}

Sistem kendali lampu yang dibuat ini dapat mengendalikan lampu ruangan pada jarak 9-17 meter dengan kondisi ruangan yang bersekat-sekat maupun rumah 2 lantai, dan jika dikendalikan dari luar rumah maka jarak jangkaunya mencapai 30-60 meter. Jarak jangkau pengendalian di pengaruhi oleh kualitas Bluetooth yang dimiliki smartphone. Pengujian dengan menggunakan smartphone Cross A88, Smartfren C2, dan Lenovo, dan hasilnya menunjukkan bahwa Bluetooth smartphone Smartfren C2 memiliki jangkauan yang paling jauh yaitu 20 meter untuk dalam ruang tertutup, dan 62 meter dari raungan terbuka atau dari luar rumah.

\section{Daftar Pustaka}

[1] Masinambow V., "Pengendalian Saklar Listrik Melalui Ponsel Pintar Android”, E-journal Teknik Elektro dan Komputer, 2301-8402, 2014

[2] Kadir A., "Panduan Praktis Mempelajari Aplikasi Mikrokontroler dan Pemrogramannya Menggunakan Arduino", Andi, Yogyakarta, 2013.

[3] McRoberts, Michael, 2010, "Beginning Arduino", Apress, New York.

[4] Aziz, M.A., Kontrol Lampu Pada Gedung Bertingkat Berbasis Personal Computer (PC), Jurnal Neutrino, 1 (2), 142-152. 2009.

[5] Hermawan D.F., "Penggunaan Teknologi Java Pada Sistem Pengendali Peralatan Elektronik Melalui Bluetooth", Jurnal Teknik Elektro, 2007.

[6] Winarno E., dan Zaki A., "Membuat Sendiri Aplikasi Android Untuk Pemula”, PT Elekmedia Computindo, Jakarta, 2011.

[7] Puspadini, Ratih T.,dan Bahriun A., "Perancangan Sistem Kontrol Penerangan, Pendingin Ruangan, Dan Telepon Otomatis Terjadwal Berbasis Mikrokontroler", Singuda Ensikom Vol.4 No. 2 , November 2014.

[8] Sawidin S., Engelin Melo O., dan Marsela T., "Monitoring Kontrol Greenhouse untuk Budidaya Tanaman Bunga Krisan dengan LabView", J NTETI, Vol. 4, No. 4, November 2015.

[9] Supriono, Seno D. Panjaitan, "Manajemen Daya Listrik dengan Sistem Automatic Transfer and Synchronization Switch berbasis PLC", JNTETI, Vol. 4, No. 3, Agustus 2015. 